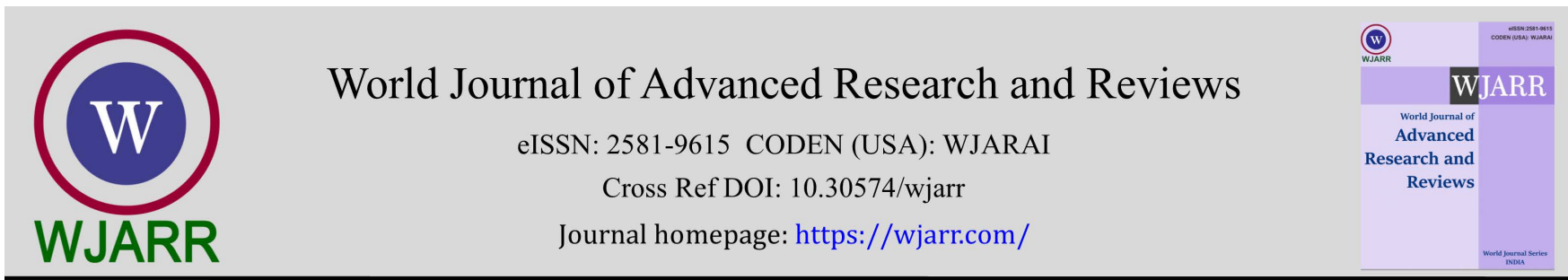

(RESEARCH ARTiClE)

\title{
Efficacy of some conventional fungicides and essential oils against tomato early blight disease
}

\author{
Ahmed S. Abdel-Aty *, Elsayed A.M. Abdallah, Ezzat A. kaduos and Mohamed R. A. Gad \\ Department of Pesticide Chemistry and Technology, Faculty of Agriculture, Alexandria University, 21545 El-Shatby, \\ Alexandria, Egypt.
}

World Journal of Advanced Research and Reviews, 2021, 10(01), 094-104

Publication history: Received on 13 February 2021; revised on 24 March 2021; accepted on 27 March 2021

Article DOI: https://doi.org/10.30574/wjarr.2021.10.1.0103

\begin{abstract}
Fungicidal activity of nine selected conventional fungicides, identified five plant oils and their combined effect against A. solani, the causal pathogen of early blight on tomato. GC-MS analysis of the tested oils indicated that terpene hydrocarbons (97\%) with cinnamaldehyde as the major compound; sulfur compounds; fatty acids and organo-sulfurcontaining compounds were the main components in cinnamon, garlic, mustard and onion oils, respectively. In vitro, Speedcide ${ }^{\circledR}$ (difenoconazole) and Cabrioduo $®$ (Dimethomorph + Pyraclostrobin) were the most effective against the A. solani fungus with $\mathrm{EC}_{50}$ values of 94.6 and $88.6 \mathrm{ppm}$ respectively. Toledo® (Tebuconzole) achieved EC 50 value of 631.2 ppm. Roxyl-M® was significantly more effective than Roxyl-plus $₫$ or Remik $₫$. Speedcide $₫$ alone or mixed with mandipropamid or azoxystrobin in Revus-Top $®$ or Cruze $®$ were the lowest effective in vitro. Garlic and mustard oils were more effective in liquid media than solid one. Cinnamon, onion, garlic and bitter almond oils caused moderate fungi-toxicity against early blight pathogen and could be implemented in the IPM program. Lower EC 50 values were obtained in case of combinations of fungicides with oils than separate treatments. Effect of the active conventional fungicides and plant oils on disease indices, relative disease control, chlorophyll content, sugar contents and poly phenol oxidase in tomato plants was also studied.
\end{abstract}

Keywords: Tomato; Early blight; Control, chlorophyll; Sugar; Poly phenol-loxidase

\section{Introduction}

Tomato (Lycopersicum esculentm Mill.), Solanaceae is one of the most important vegetables worldwide. Egypt shares with $6 \%$ of its world production. Beside attacking the root system by soil borne pathogens, early blight disease (EB) caused by Alternaria solani is an extremely destructive foliar disease in mature tomato [1] decreasing its yield and fruit quality sometimes up to $80 \%$ yield losses [2]. It causes early blight disease on potato too [3].

Several synthetic conventional fungicides [4] and non-traditional pesticides $[5,6]$ have been recommended against these plant pathogenic fungi. Foliar fungicides are commonly used to control early blight disease by frequent applications [7] either protectants as Mancozeb or systemic fungicides as strobilurin class [8]. Due to high expense, exposure risk, residues and the development of fungal resistance phenomena towards conventional fungicides, ecofriendly effective natural bio control agents have been recommended [9, 10]. Many plant oils control the plant pathogenic fungi delaying the resistance phenomenon and reducing the environmental hazards [11]. Pepper extracts inhibited the mycelial growth, suppressed conidia germination and reduced soft rot disease severity on tomatoes referring to phenolic compounds as promising sustainable application in crop protection [12]. Brevibacterium linens

\footnotetext{
${ }^{*}$ Corresponding author: Ahmed S. Abdel-Aty

Department of Pesticide Chemistry and Technology, Faculty of Agriculture, Alexandria University, 21545 El-Shatby, Alexandria, Egypt.
}

Copyright (C) 2021 Author(s) retain the copyright of this article. This article is published under the terms of the Creative Commons Attribution Liscense 4.0. 
and Bacillus subtilis greatly inhibit the mycelial growth of $A$. solani due to surfactins in the bacterial extracts indicating that antibiosis is a main mechanism of action [13]. Also, [14] found the essential oil from dried bitter almond novel and environmentally-friendly fungicide, which in vitro and in vivo affected common plant pathogenic fungi.

This study was conducted to investigate the fungicidal activity in vitro of nine selected conventional fungicides, five plant oils and their combined effect against $A$. solani, the causal pathogen of early blight on tomato as well as recording the disease incidence under greenhouse conditions. Determination of some biomarkers as chlorophyll content, sugar content and identification of plant oil compositions using GC-MS were carried out.

\section{Material and methods}

\subsection{The used conventional fungicides}

Speedcide ${ }^{\circledR}$ (Difenoconazole), 1-[2-[4-(4-chlorophenoxy)-2-chlorophenyl]-4-methyl-1,3-dioxolan-2-ylmethyl]-1H1,2,4-triazole.

Toledo ${ }^{\circledR}$ (Tebuconazole), ( \pm ) [2-(4-chlorophenyl) ethyl]-(1,1-dimethylethyl)-1H-1,2, 4-triazole-1-ethanol

Cruze $^{\circledR}$ (Difenoconazole + Azoxystrobin). Azoxystrobin, methyl(E)-2-[[6-(2-cyanophenoxy)-4-pyrimidinyl]oxy](methoxymethylene) benzeneacetate

Cabrioduo ${ }^{\circledR}$ (Dimethomorph + Pyraclostrobin). Dimethomorph, $(E, Z)-4-[3-(4-$ chlorophenyl)-3-(3,4-dimethoxyphenyl)1-oxo-2-propenyl]morpholine; pyraclostrobin, methyl [2-[[[1-(4-chlorophenyl)-1H-pyrazol-3-yl]oxy] methyl] phenyl] methoxycarbamate

Diemma ${ }^{\circledR}$ (Tebuconazole + Mancozeb). Tebuconazole, $( \pm$ ) [2-(4-chlorophenyl) ethyl] - (1,1-dimethylethyl)-1H-1, 2, 4triazole-1-ethanol. Mancozeb, [[1,2-ethanediylbis[carbamodithioato]](2-)]manganese mixture with [[1,2ethanediylbis[carbamodithioato]](2-)]zinc.

$\operatorname{Remik}^{\circledR}$ (Metalaxyl + Dimethomorph). Metalaxyl, methyl $N$-(2,6-dimethylphenyl)- $N$-(methoxy acetyl)-DL-alaninate.

Revus Top ${ }^{\circledR}$ (Difenoconazole + Mandipropamid). Mandipropamid, 2-(4-chlorophenyl)-N-[2-(3-methoxy-4-prop-2ynoxy-phenyl) ethyl]-2-prop-2-ynoxy-acetamide

Roxyl - plus ${ }^{\circledR}$ (Metalaxyl-copper hydroxide). Copper hydroxide $\left(\mathrm{Cu}(\mathrm{OH})_{2}\right)$.

Roxyl-M ${ }^{\circledR}($ Metalaxyl + Mancozeb).

\subsection{Tested plant oils}

Five plant oils: garlic (Allium sativum), onion (A. cepa L), bitter almond (Prunus armeniaca), mustard (Brassica campestris) and cinnamon (Cinnamomum zeylanicum Blume) were obtained from Chemical Industrial Development Company (CID), Egypt and confirmed for their constituents.

\subsection{Analysis of the used essential oils}

Essential oils were diluted in diethyl ether and $0.5 \mu \mathrm{l}$ was injected into the gas chromatography (Helwett Packard 5890)/mass spectrometry (Hewlwett Packard 5989B) (GC-MS) apparatus. This analysis was carried out in the Central Laboratory, Faculty of Agriculture, Alexandria University, Egypt. The GC column was a $30 \mathrm{~m}(0.25 \mathrm{~mm}$ id, film thickness $0.25 \mu \mathrm{m}$ ) HP-5 MS (5\% diphenyl) dimethyl-polysiloxane capillary column. The GC conditions were as follows: injector temperature, $240^{\circ} \mathrm{C}$; column temperature, isothermal at $70^{\circ} \mathrm{C}$ for $2 \mathrm{~min}$, then programmed to $280^{\circ} \mathrm{C}$ at $6^{\circ} \mathrm{C} / \mathrm{min}$ and held at this temperature for $2 \mathrm{~min}$; ion source temperature, $200^{\circ} \mathrm{C}$; detector temperature, $300^{\circ} \mathrm{C}$. Helium was used as the carrier gas at the rate of $1 \mathrm{ml} / \mathrm{min}$. The effluent of the GC column was introduced directly into the ion source of the MS. Spectra were obtained in the El mode at70 eV ionization energy. The sector mass analyzer was set to scan from 40 to 400 amu for $5 \mathrm{~s}$. The oil components were identified by comparison of their retention and mass spectra with the NIST Mass Spectral Library. 
<smiles>CC1COC(Cn2cncn2)(c2ccc(Oc3ccc(Cl)cc3)cc2Cl)O1</smiles>

Speedcide ${ }^{\bar{Q}}$ (Difenoconazole)<smiles>C#CCOc1ccc(CCNC(=O)C(OCC#C)c2ccc(Cl)cc2)cc1OC</smiles><smiles>COCC(=O)N(C(C)=O)c1c(C)cccc1C</smiles>

Metalaxyl

\section{$\mathrm{Cu}(\mathrm{OH})_{2}$}

$\operatorname{SCSNHCH}_{2} \mathrm{CH}_{2} \mathrm{NHCSSMn}_{\mathrm{x}}(\mathrm{Zn})_{\mathrm{y}}$

\section{Copper} hydroxide<smiles>COc1ccc(/C(=C/C(=O)N2CCCCC2)c2ccc(Cl)cc2)cc1OC</smiles><smiles>COc1ccc(/C(=C/C(=O)N2CCOCC2)c2ccc(Cl)cc2)cc1OC</smiles>

Dimethomorph<smiles>COC(=O)N([O-])c1ccccc1COc1ccn(-c2ccc(Cl)cc2)n1</smiles>

Pyraclostrobin<smiles>CC(C)(C)C(O)(CCCc1ccc(Cl)cc1)Cn1cncn1</smiles>

Tebuconazole<smiles>COC(=O)/C=C(/OC)c1ccccc1Oc1cc(Oc2ccccc2C#N)ncn1</smiles>

Azoxystrobin

Figure 1 Chemical structures of the tested fungicides

\subsection{Fungicidal activity measurements}

\subsubsection{Treated fungus}

Alternaria solani (Ellis and Martin) Sorrier was supplied by Plant Pathology Department, Faculty of Agriculture, Alexandria University.

\subsubsection{The used medium}

Potato or Potato dextrose agar (PDA) media were prepared (200 g sliced potatoes in 1.0 liter distilled water). $20 \mathrm{~g}$ dextrose and $20 \mathrm{~g}$ agar powder is added in PDA medium and autoclaved.

\subsubsection{Fungicidal activity (solid media)}

Radial-growth test was used according to the conventional method [15]. After solidification of the potato medium (PDA), a disc inoculum ( $5 \mathrm{~mm}$ in diameter) was centered in the Petri-dish. When the growth of the untreated fungus (control) completely covered the surface of the petri-dish, the results were recorded by measuring two vertical radii of the growth in each Petri-dish. The inhibition percent was calculated [16]. EC 50 values were determined for each tested toxicant. Data were analyzed using probit analysis [17].

\subsubsection{Fungicidal activity (liquid media)}

A definite volume of PDA medium (25 ml) with a calculated volume of distilled water was sterilized in conical flask (150 $\mathrm{ml}$ ). The required volume of the buffer solution ( $3 \mathrm{ml}$ for each one) was autoclaved separately, and then both solutions were mixed in the flask under aseptic conditions. The calculated volume of the tested toxicants was added and the 
inoculum disk ( $5 \mathrm{~mm}$ ) was finally floated under aseptic conditions. Three replicates for each treatment and control were concurrently conducted. The flasks were incubated at $25-27^{\circ} \mathrm{C}$. Observations concerning the toxicity were the time required to complete disc formation in control. Judgment was visually done daily.

\subsection{Green house experiment}

Healthy tomato seedlings were surface sterilized in $0.5 \%$ sodium hypochlorite solution for 2 min, rinsed with sterile distilled water. The petmoss was used as sown media and sterilized at $121^{\circ} \mathrm{C}$ for $20 \mathrm{~min}$, inoculated by the pathogenic fungus (200 discs/kg petmoss) and distributed in the seedling tray. In control a sterilized petmoss was used in addition to positive control of petmoss inoculated by the fungus. Treatments were applied after the appearance of wilt disease syndrome. The disease incidence was recorded after 7days application.

\subsection{Eradication activity}

The tomato Plants were treated with fungicide and plants oils after one week of inoculation that caused about $20 \%$ infection of the host plants. The plants were maintained under the glass house conditions till the real three-four leaves stage. Four pots for each treatment were made as well as control. Disease incidence was assessed as percentage of colonized leaves/plant (even when one colony appeared on the leaf). Disease development was expressed as a percentage degree of infection using the assessment key and determined by the following equation[18].

$$
\text { Disease index }(\mathrm{D} . \mathrm{I})=(\mathrm{nr} / 4 \mathrm{~N}) \times 100
$$

Where: $\mathbf{n}$, number of leaves in each category of the key; $\mathbf{r}$, numerical values given to the tested sample; $\mathbf{N}$, total number of examined leaves; 4 , freedom degree.

The category of the key was discriminated as zero means healthy plants; $1,2,3$ and 4 means one, two, three and four or more plants are infected, respectively. Relative disease control (RDC) values were calculated with the following equation:

$$
\text { RDC }=((\text { D.I of control }- \text { D.I of treatment }) / \text { D.I of control }) \times 100
$$

\subsection{Effect on fungal biomarkers}

\subsubsection{Determination of chlorophyll content}

Freshly picked leaf of pre-treated and non-treated tomato seedlings were cut into pieces, and then $250 \mathrm{mg}$ was used for determination of mg chlorophyll a, b, and total contents/ gm fresh sample at 645 and $663 \mathrm{~nm}$ [19].

\subsubsection{Polyphenol oxidase activity}

Polyphenol oxidase activity was determined in borate buffer (pH 9.0) at $575 \mathrm{~nm}$ [20].

\subsubsection{Determination of sugar contents}

1.0 gram of small species of broad bean leaves extracted by $20.0 \mathrm{ml}$ of $80 \%$ ethanol. Reduced, non-reduced and total soluble sugars contents were determined [21].

\section{Results and discussion}

\subsection{Chemical composition of the tested plant oils}

GC-MS analysis of the used five plant oils indicated variable components with different percentages among them. The relative area and constituents are recorded in Table (1). The essential oil of cinnamon was characterized by a high amount of terpene hydrocarbon compounds with cinnamaldehyde was the major volatile mono-terpene compound with the highest percent (77.7\%), followed by estragole (8.4\%), benzyl benzoate $(2.8 \%)$ and benzyl cinnamate $(2.7 \%)$. The essential garlic oil was characterized by a high amount of sulfur compounds with diallyl-tri-sulfide (39.0\%), diallyldi-sulfide (21.4\%), methyl allyldisulfide (11.9\%) and methyl allyl-tri-sulfide $(16.2 \%)$ as the major components. Fatty acids were the main components of the tested mustard oil. Its fatty acids content was oleic acid (38.3\%), erucic acid (19.3\%), linoleic acid (12.2\%) and lenolenic acid (11.4\%) as major contented fatty acids. The used essential oil of onion 
was characterized by most representative compounds that were sulfur-containing compounds as 9,12-octadecadienoic acid (14.0\%), 2-methyl-3,13-octadecadien-1-ol (9.8\%), dodecane (28.7\%), undecane (8.1\%), 2,5-dimethyl-thiophene (9.8\%), 3-methyl(methyl sulfonyl-amino)thiophene (9.0\%), 3,4-dimethyl thiophene (3.2\%) and others. The tested bitter almond oil indicated a high content of un-saturated and low saturated fatty acids as oleic acid and linoleic acid were found at 29.3 and $8.9 \%$, respectively in addition to benzaldhyde, benzyl cyanide and benzoic acid at a ratio of 4.4 , 1.0 and 2.5 , respectively.

\subsection{Fungicidal activity}

\subsubsection{In vitro effect of tested fungicides}

In vitro effects of the tested fungicides against $A$. solani the causal pathogen of tomato plants early blight are recorded in Table (2). Using the solid potato dextrose agar medium, it is revealed that Spaeedcide ${ }^{\circledR}$ (difenoconazole) and Cabrioduo $^{\circledR}$ (Dimethomorph + Pyraclostrobin) were the most effective tested fungicides against the treated fungus with $\mathrm{EC}_{50}$ values of 94.6 and $88.6 \mathrm{ppm}$, respectively.

While Toledo ${ }^{\circledR}$ (Tebuconzole) belongs to triazole group as Speedcide ${ }^{\circledR}$ with the same mode of action by inhibiting the sterol formation of the all fungus membrane, it showed the highest EC 50 value obtained in this respect of all tested fungicides $(631.2 \mathrm{ppm})$ that indicates the specificity of such compounds. Metalaxyl mixed with mancozeb in the formulation of Roxyl-M ${ }^{\circledR}$ was significantly more effective against $A$. solani than matalaxyl with copper hydroxide (Roxylplus $^{\circledR}$ ) or with dimethomorph (Remik ${ }^{\circledR}$ ) that the EC 50 values were 205.5, 509.3 and 566.8 for Roxyl-M ${ }^{\circledR}$, Roxyl-plus ${ }^{\circledR}$ and $\operatorname{Remik}^{\circledR}$, respectively. When mancozeb was mixed with tebuconazole or metalaxyl, the fungicidal activity has promoted remarkably and the $\mathrm{EC}_{50}$ values decreased markedly from 631.2 to 531.6 of Toledo $^{\circledR}$ and Dimma ${ }^{\circledR}$, respectively. In addition, combination of mancozeb with metalaxyl was very effective against the early blight causal fungus more than mixing metalaxyl with copper hydroxide or dimethomorph where the EC50 values were 205.8, 509.3 and 566.8 for Dimma ${ }^{\circledR}$, Roxyl-M ${ }^{\circledR}$ and Roxyl-plus ${ }^{\circledR}$, respectively. The relative potency of Toledo ${ }^{\circledR}$ (Tebuconzole) was 0.14 of Speedcide ${ }^{\circledR}$ (difenoconazole), in spite of both compounds of the same triazole group.

Table 1 Chemical composition of the tested plant oils major compounds.

\begin{tabular}{|c|c|c|c|c|}
\hline The oil & No & Major components & Mass & Area\% \\
\hline \multirow{7}{*}{$\begin{array}{l}\text { Cinammon oil } \\
\text { C. zeylanicum }\end{array}$} & 1 & 2-Methoxy-2-phenylacetic acid & 166.1 & 2.6 \\
\hline & 2 & Cinnamaldehyde & 132.1 & 77.7 \\
\hline & 3 & Estragole & 148.1 & 8.4 \\
\hline & 4 & Methoxymethyl)-benzene & 122.1 & 1.4 \\
\hline & 5 & Benzyl benzoate & 212.1 & 2.8 \\
\hline & 6 & Benzyl cinnamate & 238.1 & 2.7 \\
\hline & 7 & Ethyl-4-(3-phenylpropyl)benzoate & 268.2 & 2.1 \\
\hline \multirow{9}{*}{$\begin{array}{l}\text { Garlic oil } \\
\text { A. sativum }\end{array}$} & 1 & Ethyl vinyl sulfide & 88.0 & 2.2 \\
\hline & 2 & Diallyl sulfide & 114.1 & 2.1 \\
\hline & 3 & Methyl allyl disulfide & 120.0 & 11.9 \\
\hline & 4 & Dimethyl trisulfide & 126.0 & 2.0 \\
\hline & 6 & Diallyl disulfide & 146.0 & 21.4 \\
\hline & 7 & Methyl allyl trisulfide & 152.0 & 16.2 \\
\hline & 8 & 3-Vinyl-[4H]-1,2-dithiin & 144.0 & 3.7 \\
\hline & 9 & Diallyl trisulfide & 178.0 & 39.0 \\
\hline & 10 & Diallyl tetrasulfide & 210.0 & 0.9 \\
\hline \multirow{2}{*}{ Mustard oil } & 1 & Palmitic Acid (C16:0) & 256.2 & 2.5 \\
\hline & 2 & Lignoceric Acid (C24:0) & 368.4 & 9.6 \\
\hline
\end{tabular}




\begin{tabular}{|c|c|c|c|c|}
\hline \multirow{6}{*}{$\begin{array}{c}\text { Brassica } \\
\text { campestris }\end{array}$} & 3 & Oleic Acid (C18:1) & 282.3 & 38.3 \\
\hline & 4 & Eicosenoic Acid (C20:1) & 310.3 & 5.5 \\
\hline & 5 & Erucic Acid (C22:1) & 338.3 & 19.3 \\
\hline & 6 & Linoleic Acid (C18:2) & 280.2 & 12.2 \\
\hline & 7 & Linolenic Acid (C18:3) & 278.2 & 11.4 \\
\hline & 8 & Docosapentaenoic Acid (C22:5) & 330.3 & 0.7 \\
\hline \multirow{13}{*}{$\begin{array}{l}\text { Onion oil } \\
\text { A. cepa L }\end{array}$} & 1 & Cyclotetradecane & 196.1 & 2.6 \\
\hline & 2 & 2-(3,7-Dimethyl-octa-2,6-dienyl)-4-methoxyphenol & 260.3 & 1.2 \\
\hline & 3 & n-Hexadecanoic acid & 256.2 & 2.8 \\
\hline & 4 & 9,12-Octadecadienoic acid & 280.1 & 14.0 \\
\hline & 5 & 2-Methyl-3,13-octadecadien-1-ol & 280.1 & 9.8 \\
\hline & 6 & 2,3-Dihydroxypropyl ester-9-octadecenoic acid & 357.0 & 3.2 \\
\hline & 7 & 2,6-Bis(3,4-methylene dioxyphenyl)-3,7-dioxa bicycloctane & 355.0 & 6.1 \\
\hline & 8 & 3,4-Dimethyl thiophene & 112.0 & 3.2 \\
\hline & 9 & Undecane & 156.0 & 8.1 \\
\hline & 10 & 3-Methyl(methyl sulfonylamino)thiophene & 249.0 & 9.0 \\
\hline & 11 & Dodecane & 170.0 & 28.7 \\
\hline & 12 & 1,2-Dithiolane,1,1-dioxide & 138.0 & 1.6 \\
\hline & 13 & 2,5-Dimethyl-thiophene & 112.0 & 9.8 \\
\hline \multirow{8}{*}{$\begin{array}{c}\text { bitter almond } \\
\text { oil } \\
\text { P. armeniaca }\end{array}$} & 1 & Stearic acid (C18:0) & 284.3 & 2.5 \\
\hline & 3 & Oleic acid (C18:1) & 282.2 & 29.3 \\
\hline & 4 & Linoleic acid (C18:2) & 280.2 & 8.9 \\
\hline & 6 & Benzaldehyde & 106.1 & 4.4 \\
\hline & 7 & Eucalyptol & 154.0 & 1.0 \\
\hline & 8 & (1-Propylnonyl)-benzene & 246.2 & 4.3 \\
\hline & 9 & Benzoic acid & 122.0 & 2.5 \\
\hline & 10 & Benzyl cyanide & 117.1 & 1.0 \\
\hline
\end{tabular}

Using the potato dextrose liquid medium, mancozeb moiety when mixed with tebuconzole forming Dimma ${ }^{\circledR}$ or with metalaxyl under Roxyl-M ${ }^{\circledR}$ exhibited the highest fungitoxic action against $A$. solani without significance between them with $\mathrm{EC}_{50}$ values of 141.7 and $208.2 \mathrm{ppm}$, respectively, while tobuconazole alone (Toledo ${ }^{\circledR}$ ) showed a moderate effect against the pathogen with $\mathrm{EC}_{50}$ value $299.6 \mathrm{ppm}$. Also mancozeb with metalaxyl (Roxyl-M ${ }^{\circledR}$ ) was more effective than mixing metalaxyl with copper hydroxide or dimethomorph in Roxyl-plus ${ }^{\circledR}$ and Remik $^{\circledR}$ with $\mathrm{EC}_{50}$ values equaled 208.2, 297.4 and 371.7 ppm respectively. Difenoconazole alone as Speedcide ${ }^{\circledR}$ or mixed with mandipropamid or azoxystrobin forming Revus Top ${ }^{\circledR}$ or Cruze ${ }^{\circledR}$ were the lowest effective tested fungicides against the treated pathogen in vitro using food poisoned liquid medium where the $\mathrm{EC}_{50}$ values were the highest values obtained in this respect compared with the other tested fungicides. Mancozeb as zinc and manganese salt of ethylene bis-dithiocarbamate compound when mixed with either tebuconazole or metalaxyl exhibited the highest fungicidal effect against the concerning pathogen when applied in potato dextrose liquid medium. The lowest effective fungicide showed the highest $\mathrm{EC}_{50}$ values (537.4 ppm) with the difenoconazole plus azoxystrobin formulation. In conclusion, the tested conventional fungicides gave moderate effects against $A$. solani except the $\mathrm{Cruze}^{\circledR}$, which was low toxic to the treated fungus. 
Table 2 Effect of the tested fungicides on A. solani growth; shown as $\mathrm{EC}_{50}$ values.

\begin{tabular}{|c|c|c|c|c|c|c|c|}
\hline \multirow{2}{*}{ Used medium } & \multirow{2}{*}{ Tested fungicide } & \multirow{2}{*}{$\begin{array}{c}\mathrm{EC}_{50} \\
\text { (ppm) }\end{array}$} & \multicolumn{2}{|c|}{ 95\% C. L. } & \multirow{2}{*}{$\gamma^{2}$} & \multirow{2}{*}{ Slope } & \multirow{2}{*}{ R.P } \\
\hline & & & Lower & Upper & & & \\
\hline \multirow{9}{*}{$\begin{array}{l}\text { Potato dextrose } \\
\text { agar medium } \\
\text { (Solid) }\end{array}$} & SPEEDCIDE ${ }^{\circledR}$ & 94.6 & 17.1 & 180.5 & 1.1 & 1.0 & 1.0 \\
\hline & REVUS-TOP ${ }^{\circledR}$ & 159.7 & 70.4 & 240 & 0.9 & 1.3 & 0.59 \\
\hline & $\mathrm{CRUZE}^{\circledR}$ & 168.6 & 71.0 & 256 & 3.2 & 1.2 & 0.56 \\
\hline & TOLEDO $^{\circledR}$ & 631.2 & 535 & 640 & 1.9 & 1.9 & 0.14 \\
\hline & DIEMMA $^{\circledR}$ & 531.6 & 375 & 698 & 2.1 & 1.1 & 0.17 \\
\hline & ROKSYL M ${ }^{\circledR}$ & 205.8 & 136.3 & 268 & 2.8 & 1.8 & 0.45 \\
\hline & ROKSYL PLUS ${ }^{\circledR}$ & 509.3 & 436 & 585 & 3.6 & 2.2 & 0.18 \\
\hline & REMIK ${ }^{\circledR}$ & 566.8 & 459 & 684 & 4.6 & 1.6 & 0.16 \\
\hline & CABRIODUO $^{\circledR}$ & 88.6 & 11.9 & 178 & 2.3 & 0.9 & 1.06 \\
\hline \multirow{9}{*}{$\begin{array}{l}\text { Potato dextrose } \\
\text { medium } \\
\text { (liquid) }\end{array}$} & SPEEDCIDE $^{\circledR}$ & 351.7 & 277.6 & 419.7 & 3.4 & 1.9 & 1.0 \\
\hline & REVUS-TOP ${ }^{\circledR}$ & 361.7 & 252 & 458.9 & 1.2 & 1.4 & 0.97 \\
\hline & CRUZE $^{\circledR}$ & 537.4 & 386.3 & 698.8 & 5.4 & 1.1 & 0.65 \\
\hline & TOLEDO $^{\circledR}$ & 299.6 & 157.7 & 417 & 5.8 & 1.0 & 1.17 \\
\hline & DIEMMA $^{\circledR}$ & 141.7 & 24.1 & 256.8 & 1.1 & 0.8 & 2.4 \\
\hline & ROKSYL M ${ }^{\circledR}$ & 208.2 & 64.6 & 330.3 & 3.1 & 0.9 & 1.6 \\
\hline & ROKSYL PLUS ${ }^{\circledR}$ & 297.4 & 197.4 & 383.9 & 0.8 & 1.4 & 1.1 \\
\hline & REMIK $^{\circledR}$ & 371.7 & 244.5 & 483.2 & 4.2 & 1.2 & 0.94 \\
\hline & CABRIODUO $^{\circledR}$ & 239.3 & 194.2 & 385.6 & 12.6 & 1.5 & 1.4 \\
\hline
\end{tabular}

$\mathbf{R P}$, relative potency; $\mathbf{9 5 \%} \mathbf{C L}, 95 \%$ Confidence limit; $\boldsymbol{\gamma}^{2}, \mathrm{Chi}^{2}$

\subsection{Fungicidal activity of the tested oils $A$. solani}

As shown in Table (3), comparing the $\mathrm{EC}_{50}$ values, garlic and mustard oils showed more fungitoxic effect using liquid medium than solid one with $\mathrm{EC}_{50}$ values of 384.6, 329.7 and 293.7 comparing with 502.9 and $>1500$ ppm, respectively. Variation in $\mathrm{EC}_{50}$ values of mustard oil between the two media may be due to its high concentration of cic-vaccenic acid and 9,12-octadecadienoic acid that might be more soluble in liquid media than distribution in solid one. On contrary to onion and bitter almond oils that were more effective in solid medium than the liquid one with EC50 values of 302.7 and 305.8 ppm compared with 532.8 and 403.1 ppm, respectively. Mustard oil caused remarkable degree of fungtoxic effect using liquid media technique with $\mathrm{EC}_{50}$ value of $293.7 \mathrm{ppm}$, however its highest concentration did not reach $50 \%$ inhibition of the fungal mycelial growth in soil media technique. Cinnamon oil showed high degree of fungitoxicity against the treated fungus in both techniques with $\mathrm{EC}_{50}$ values of 290.3 and 301ppm, respectively. Cinnamon, onion, garlic and bitter almond oils proved to possess a moderate degree of fungitoxicity against early blight pathogen and could be substituted for the conventional fungicides and implemented is the IPM program. 
Table 3 Effect of tested oils on the growth of $A$. solani; shown as $\mathrm{EC}_{50}$ values.

\begin{tabular}{|c|c|c|c|c|c|c|c|}
\hline \multirow[t]{2}{*}{ Technique } & \multirow[t]{2}{*}{ Oil plant } & \multirow{2}{*}{$\begin{array}{c}E_{50} \\
(p p m)\end{array}$} & \multicolumn{2}{|c|}{ 95\% C. L. } & \multirow{2}{*}{$\gamma^{2}$} & \multirow{2}{*}{ Slope } & \multirow{2}{*}{ R.P } \\
\hline & & & Lower & Upper & & & \\
\hline \multirow{5}{*}{$\begin{array}{l}\text { Potato } \\
\text { dextrose } \\
\text { agar } \\
\text { medium } \\
\text { (Solid) }\end{array}$} & Onion (A. сера L.) & 302.7 & 146.9 & 430 & 1.03 & 0.9 & 1.0 \\
\hline & Garlic (A. sativum) & 502.9 & 393.7 & 613.4 & 4.6 & 1.4 & 0.6 \\
\hline & Bitter almond (P. armeniaca) & 305.8 & 64.7 & 491.9 & 1.2 & 0.7 & 0.98 \\
\hline & Mustard (B. campestris) & $>1500$ & & & & & \\
\hline & Cinnamon (C. zeylanicum) & 290.3 & 161.3 & 398.3 & 0.5 & 1.12 & 1.04 \\
\hline \multirow{5}{*}{$\begin{array}{l}\text { Potato } \\
\text { dextrose } \\
\text { medium } \\
\text { (liquid) }\end{array}$} & Onion (A. cepa L.) & 532.8 & 440.5 & 629 & 1.0 & 1.8 & 3.7 \\
\hline & Garlic (A. sativum) & 384.6 & 286.3 & 474.3 & 1.38 & 1.5 & 3.8 \\
\hline & Bitter almond (P. armeniaca) & 403.1 & 295.2 & 502 & 1.32 & 1.4 & 1.9 \\
\hline & Mustard (B. campestris) & 293.7 & 116.7 & 435.5 & 1.8 & 0.8 & 0.71 \\
\hline & Cinnamon (C. zeylanicum) & 301 & 194.3 & 392.7 & 1.77 & 1.3 & 3.6 \\
\hline
\end{tabular}

\subsection{Fungicidal effect of the combined effective fungicides and oils}

From Table (4), The $\mathrm{EC}_{50}$ values of these combinations were lower as 286.2 ppm for Revus-Top ${ }^{\circledR}$ and garlic oil mixture comparing with 384.6 and 361 ppm for each indicating higher fungitoxic effect (potentiative effect) of this combination. Mixing garlic oil with Cabrioduo caused its fungal toxicity with 317.3 ppm EC 50 value in comparison to 384.6 and 239.3 ppm for garlic oil and Cabriodue, respectively. Combination of onion oil and Revus-Top $®$ enhanced the toxicity than either each alone with $\mathrm{EC}_{50}$ value of 334.1 ppm. However an additive effect was achieved when mixed with Cabrioduo® conventional fungicide with $\mathrm{EC}_{50}$ value of $391.8 \mathrm{ppm}$. Lower $\mathrm{EC}_{50}$ values were obtained in case of combinations than separate treatments indicating raise of fungicidal efficiency that may be due to multiple action sites, and facilitating access to the impact center and fungus cell because of presence of oils. The range of $\mathrm{EC}_{50}$ values obtained in this experiment led to the possibility of mixing the conventional fungicides with these plant oils in order to decrease the chemicals release to the environment, reduce the cost, and delay the resistance phenomena, in pathogenic fungi.

Table 4 Effects of tested oils and fungicides mixtures against $A$. solani; shown as $\mathrm{EC}_{50}$ values.

\begin{tabular}{|c|c|c|c|c|c|c|c|c|}
\hline \multirow{2}{*}{ Value } & \multicolumn{7}{|c|}{ Tested fungicides and oils mixtures } \\
\cline { 2 - 10 } & $\begin{array}{c}\text { Garlic } \\
\text { Oil (G0) }\end{array}$ & $\begin{array}{c}\text { Onion } \\
\text { Oil (00) }\end{array}$ & CAB. & 00 + CAB. & GO + CAB. & REV. & O0 + REV & GO + REV. \\
\hline EC $_{\mathbf{5 0}}$ & 384.6 & 532.8 & 239.3 & 391.8 & 317.3 & 361.7 & 334.1 & 286.2 \\
\hline $\mathbf{9 5 \%}$ C.L & $286-474.3$ & $440.5-629$ & $194-385.6$ & $293-482$ & $215.5-406$ & $252-459$ & $234-422$ & $203.5-359$ \\
\hline$\gamma^{2}$ & 1.38 & 1.0 & 1.26 & 2.1 & 5.6 & 1.2 & 2.9 & 3.0 \\
\hline Slope & $1.5 \pm 0.08$ & $1.8 \pm 0.09$ & $1.5 \pm 0.03$ & $1.54 \pm 0.4$ & $1.4 \pm 0.01$ & $1.4 \pm 0.2$ & $1.46 \pm 0.1$ & $1.6 \pm 0.01$ \\
\hline
\end{tabular}

95\%CL, 95\%; Confidence limit; $\gamma^{2}$, $\mathrm{Chi}^{2}$; CAB, CABRIODUO; REV, REVUS-TOP

\subsection{Effects on disease incidence and tomato biomarkers}

\subsubsection{Disease incidence}

As recorded in Table (5), the disease incidence of tomato early blight causal agent showed that Revus-Top ${ }^{\circledR}$ and Cabrioduo $^{\circledR}$ were more effective in reducing it from $42.8 \%$ to 9.7 and $12.4 \%$, respectively. The relative disease control was the highest in case of Revus-Top ${ }^{\circledR}(77.3 \%)$ of the control followed by Cabrioduo ${ }^{\circledR}(71.0 \%)$. The oils were less effective in reducing disease incidence than the chemical fungicides. Garlic and onion oils recovered $47.9 \%$ and $35.6 \%$ of control, respectively. Treatment with garlic oil, which is ecofriendly and easy obtainable oil helps in early blight disease recovery more than onion oil. This effect may be due to its high content of sulfure compounds that are known for good control of fungi. 


\subsubsection{Chlorophyll content}

Treatments with Revus-Top ${ }^{\circledR}$, Cabrioduo ${ }^{\circledR}$ and onion showed very weak non-significant effects on tomato chlorophyll contents except onion and garlic oils that gave increasing effect in chlorophyll content comparing with control plants. Only onion oil treatment enhanced the amount of all chlorophyll types significantly. These findings revealed low phytotoxicity against tomato chlorophyll contents.

Table 5 Effect of the tested oils and fungicides on A. solani; shown as disease incidence (DI), relative disease control (RDC), chlorophyll content, sugar content and polyphenol oxidase activity.

\begin{tabular}{|c|c|c|c|c|c|c|c|c|c|}
\hline \multirow{2}{*}{$\begin{array}{c}\text { Tested } \\
\text { materials }\end{array}$} & \multirow{2}{*}{$\begin{array}{l}\text { DI } \\
\%\end{array}$} & \multirow{2}{*}{$\begin{array}{c}\text { RDC } \\
\%\end{array}$} & \multicolumn{3}{|c|}{$\begin{array}{c}\mu \mathrm{g} \text { chlorophyll /g leaves } \\
\times 10^{-2}\end{array}$} & \multicolumn{3}{|c|}{ Effect on sugar contents } & \multirow{2}{*}{$\begin{array}{c}\text { PPO } \\
\text { activity \% } \\
\text { Mean } \pm \text { SE }\end{array}$} \\
\hline & & & Chl. A & Chl. B & Total & R.S & N.R.S & T.S.S & \\
\hline REVUS-TOP $^{\circledR}$ & 9.7 & 77.3 & $27 \pm 1.7$ & $46 \pm 0.3$ & $74 \pm 1.7$ & $\begin{array}{c}11.08 \pm \\
0.18 \\
\end{array}$ & $10.20 \pm 0.32$ & $21.2 \pm 0.35$ & $12.1 \pm 0.6$ \\
\hline CABRIODUO $^{\circledR}$ & 12.4 & 71.0 & $25 \pm 1.9$ & $45 \pm 0.7$ & $70 \pm 2.3$ & $10.5 \pm 0.21$ & $7.8 \pm 0.46$ & $18.4 \pm 0.25$ & $14.3 \pm 0.7$ \\
\hline ONION & 27.4 & 35.6 & $34 \pm 1.2$ & $47 \pm 0.8$ & $81 \pm 1.2$ & $12.5 \pm 0.17$ & $11.1 \pm 0.37$ & $23.6 \pm 0.20$ & $5.4 \pm 0.4$ \\
\hline GARLIC & 22.3 & 47.9 & $29 \pm 0.4$ & $45 \pm 0.7$ & $75 \pm 1.1$ & $11.9 \pm 0.15$ & $10.1 \pm 0.19$ & $22.03 \pm 0.13$ & $6.8 \pm 0.4$ \\
\hline Control & 42.8 & 0.00 & $26 \pm 0.8$ & $43 \pm 0.7$ & $70 \pm 1.1$ & $11.6 \pm 0.18$ & $11.3 \pm 0.32$ & $22.9 \pm 0.18$ & $9.3 \pm 0.3$ \\
\hline $\operatorname{LSD}_{(0.05)}$ & & & 4.2 & 4.3 & 4.5 & 0.57 & 1.07 & 0.72 & 1.6 \\
\hline
\end{tabular}

RDC, relative disease control; DI, disease incidence; R.S,reducing sugars; N.R.S non-reducing sugars; T.S.S, total soluble sugars; PPO, polyphenoloxidase

\subsubsection{Sugar contents}

The obtained changes in sugar contents were non-significant compared with the untreated leaves. Only Cabrioduo ${ }^{\circledR}$ reduced the non-reducing and total sugar content from 11.3 to $7.8 \mathrm{mg}$ and from 22.9 to 18.4 glucose/g fresh tomato leaves, respectively. All other changes of the sugar contents were non-significant compared with control leaves.

\subsubsection{Polyphenol oxidase (PPO) activity}

Treatments of tomato leaves with selected fungicides and oils caused remarkable changes of PPO activity. Conventional fungicides raised the PPO activity significantly from 9.3 to 12.1 and 14.3 in case of control, Revus-Top ${ }^{\circledR}$ and Cabrioduo ${ }^{\circledR}$, in the same array. On the contrary, onion and garlic oils reduced its activity from 9.3 in control to 5.4 and 6.8 , respectively.

From the obtained results, the potential use of essential oils either alone or in combinations with conventional fungicides was effective in controlling the early blight disease of tomato plant especially the mixtures of Cabrioduo ${ }^{\circledR}$ and Revus-Top ${ }^{\circledR}$ with onion and garlic oils. Plant oils have the great potential to be developed as botanical fungicides. The different antifungal activity of tested essential oils may be due to the differences in their antimicrobial contents [22]. The results showed a significant reduction against early blight compared to control with no adverse effect. Garlic and onion oils inhibited the mycelial growth of $A$. solani pathogenic fungus. The present study also suggests that the application of essential oils alone or in along with conventional fungicides may overcome this pathogen infection by increasing the levels of defense related enzymes in agreement with [23]. Plants protect themselves against phytopathogenic agents by producing a wide range of antimicrobial compounds among them, polyphenol oxidase (PPO), which was affected by both of the tested conventional fungicides and plant oils as a mechanism of disease suppression [24].

\section{Conclusion}

In conclusion, the used essential oils appeared effective against the tomato early blight disease comparing with control either alone or when mixed with the conventional fungicides. Their different may be due to the differences in their antimicrobial contents. This study revealed that the application of essential oils overcome this pathogen infection by increasing the levels of defense related enzymes as developing new botanical fungicides. 


\section{Compliance with ethical standards}

\section{Acknowledgments}

The authors acknowledge the staff member of Pesticide Synthesis and Biochemical Studies Laboratory, Faculty of Agriculture, Alexandria University, Egypt for their cooperation and moral support.

\section{References}

[1] Soliman AMM. Assessment of conventional fungicides and biochemical extracts against soil borne fungi, MSc thesis, Faculty of Agriculture, Alexandria University. 2015.

[2] Patel SJ, Subramanian RB, Jha YS. Biochemical and molecular studies of early blight disease in tomato. Phytoparasitica 2011. Doi. Org/101007/st2600 - $011-0156-6$.

[3] Eva E. Species specific primers for identification of Alternaria solani, in combination with analysis of the F129L substitution associates with loss of sensitivity towards trobilurins. Crop Protection. 2012; $38: 72$ - 73.

[4] Weitang S, Zhou L, Yang C, Cao X, Zhang L, Liu X. Tomato Fusarium wilt and its chemical control strategies in a hydroponic system. Crop Protection 2004, 23: 243-247.

[5] Abdel-Aty AS. Fungicidal activity of certain indole derivatives against some plant pathogenic fungi. Journal of Pesticide Science. 2010; 35(4): 431-440.

[6] Abdel-Aty AS, Desheesh MA, Allam AM. Antimicrobial and biochemical activities of some aryl azomorpholine derivatives. Asian Journal of Chemistry. 2015; 27(10): 3579 - 3585.

[7] Pscheidt JW, Stevenson WR. The critical Period for control of early blight Alternaria solaniand of potato. American Potato Journal 1988, 65 (8), 425 - 438.

[8] Bartlett DW, Clough JM, Godwin JR, AA, Hamer M, Parr - Dobrzanski B. The strobilurin fungicides. Pest Management Science. 2002; 58: 649 - 662.

[9] Latha P, Anand T, Ragupathi N, Prakasam V, Samiyappan R. Antimicrobial activity of plant extracts and induction of systemic resistance in tomato plant by mixtures of PGOR strains and Zimmu leaf extract against Alternaria solani. Biological Control. 2009; 50: 85 - 93.

[10] Anand T, Chandrasekaran A, Kuttalam S, Senthilraja G, Samiyappan R. Integrated control of fruit rot and powdery mildew of chili using the bio control agent pseudomonas fluorescence and a chemical fungicide. Biological Contol. 2010; 52: 1 - 7 .

[11] Sokovie M, Vukojevic D, Marin PD, Brkic DD, Vajs V, Van Griensven LJ. Chemical composition of essential oils of Thymus and Mentha species and their antifungal activities. Molecules. 2009; 14(1): 238 - 249.

[12] Catello P, Fratianni F, Parisi M, Nazzaro F, Zaccardelli M. Control of Alternaria post-harvest infections on cherry tomato fruits by wild pepper phenolic-rich extracts. Crop Protection. 2016; 84: 81 - 87.

[13] Anna O, Wong F, Ko Q, Tweddell RJ, Antounand H, Avis TJ. Antifungal effects of tea compost microorganisms on tomato pathogens. Biological Control. 2015; 80: 63 - 69.

[14] Huiling G, Yu X, Lu A, Cao H, Zhou B, Zhou Le, Zhao Z. Extraction, chemical composition, and antifungal activity of essential oil of bitter almond. International Journal Molecular Science. 2016; 1 - 14.

[15] Torgeson DC. Fungicides.Vol.1. Agricultural and industrial applications environ-mental interactions. Academic Press New York and London. 1967.

[16] Topps JH, Wain RL. Investigation on fungicides ш. The fungitoxicity of 4- and 5-alkylsalicylanilide and p-chloroanilines. Annual Applied Biology. 1957; 45(3): 506 - 511.

[17] Finney DJ. Probit analysis, 3 $3^{\text {rd }}$ ed Cambridge, UK: University Press. 1971.

[18] Wenzl H. The basic principles of crop protection field trials. Planzechutz Nachirchten (Bayer). $1948 ; 16: 82$ - 162.

[19] Grodzinsky AM, Grodzinsky DM. Short reference in plant physiology. Naukova Domka, R. U. R. $1973 ; 433-434$.

[20] Broesch S. Colorimetric assay of phenol oxidase. Bull. Sac. Chem. Biol. 1964; 36: 711- 713.

[21] Thomas W, Dutcher RA. Picric acid method for carbohydrate. J. American. Chemical Society. $1924 ; 46: 1662$ - 69. 
[22] Tassou CC, Koustomanis K, Nychas JG. Inhibition of Salmonella enteritidis and Staphylococcus aureus in nutrient broth by mint essential oil. Food Research Inter. 2000; 33: 273-280.

[23] Pal GK, Kumar B. Antifungal activity of some common weed extracts against wilt causing fungi Fusarium oxysporum. Current Discovery. 2013; 2(1): 62 - 67.

[24] Xue L, Charest PM, Jabaji-Hare SH. Systemic induction of peroxidase, $B-1,3$ glucanases, chitinases and resistance in bean plants by bi-nucleate. Rizoctonia species. Phytopathology. 1998; 88: 359 - 365. 